\title{
Rangeland health attributes and indicators for qualitative assessment
}

\author{
DAVID A. PYKE, JEFFREY E. HERRICK, PATRICK SHAVER, AND MIKE PELLANT
}

Authors are Research Rangeland Ecologist, U.S. Department of the Interior, U.S. Geological Survey, Forest \& Rangeland Ecosystem Science Center, Corvallis, Ore., 97331, david_a pyke@usgs.gov; Research Scientist, U.S. Department of Agriculture, Agricultural Research Service, Jornada Experimental Range, Las Cruces, N.M. 88003, jherrick@nmsu.edu; Rangeland Management Specialist, U.S. Department of Agriculture, Natural Resources Conservation Service, Grazing Land Technology Institute, Department of Rangeland Resources, Oregon State University, Corvallis, Ore. 97331, patrick.shaver@orst.edu; and Rangeland Ecologist, U.S. Department of the Interior, Bureau of Land Management, Idaho State Office, Boise, Ida.83709, mike_pellant@blm.gov.

Abstract

Panels of experts from the Society for Range Management and the National Research Council proposed that status of rangeland ecosystems could be ascertained by evaluating an ecological site's potential to conserve soil resources and by a series of indicators for ecosystem processes and site stability. Using these recommendations as a starting point, we developed a rapid, qualitative method for assessing a moment-in-time status of rangelands. Evaluators rate 17 indicators to assess 3 ecosystem attributes (soil and site stability, hydrologic function, and biotic integrity) for a given location. Indicators include rills, water flow patterns, pedestals and terracettes, bare ground, gullies, wind scour and depositional areas, litter movement, soil resistance to erosion, soil surface loss or degradation, plant composition relative to infiltration, soil compaction, plant functional/structural groups, plant mortality, litter amount, annual production, invasive plants, and reproductive capability. In this paper, we detail the development and evolution of the technique and introduce a modified ecological reference worksheet that documents the expected presence and amount of each indicator on the ecological site. In addition, we review the intended applications for this technique and clarify the differences between assessment and monitoring that lead us to recommend this technique be used for moment-in-time assessments and not be used for temporal monitoring of rangeland status. Lastly, we propose a mechanism for adapting and modifying this technique to reflect improvements in understanding of ecosystem processes. We support the need for quantitative measures for monitoring rangeland health and propose some measures that we believe may address some of the 17 indicators.

Key Words: Soil stability, hydrologic function, biological integrity, ecosystem status, erosion, infiltration, inventory

BLM, NRCS, USGS and ARS jointly funded this project. Authors wish to thank Drs. B. Bestelmeyer, J. Alexander, L. Eddleman, M. Karl, W.C. Krueger, M. Kothmann, W. Laycock, M. Miller, P. Sims, E.L. Smith, T. Stohlgren, S. Swanson, G. Tanner, T. Thurow, J. Trlica, various BLM and NRCS staff, the Association of Rangeland Consultants, Western Coordinating Committee on Rangeland Ecological Research \& Assessment for helpful input that improved this technique; G. Frasier and three anonymous reviewers for their critical comments that improved this manuscript; D. Toledo and A. Melgoza for drafting the Spanish version of the abstract.

Manuscript accepted 6 Mar. 2002.

\section{Resumen}

Un panel de expertos de la "Society for Range Management" $y$ el "National Research Council" propusieron que el estado de los ecosistemas de los agostaderos podría ser determinado evaluando el potencial que un sitio ecológico tiene para conservar recursos del suelo, y por una serie de indicadores de procesos ecológicos y estabilidad del sitio. Utilizando estas recomendaciones como punto de partida, desarrollamos un rápido método cualitativo para evaluar el estado de agostaderos en un punto especifico en el tiempo. Se evaluaron 17 indicadores para asesorar 3 atributos del ecosistema (suelo y estabilidad del sitio, función hidrológica, e integridad biótica) para un sitio especifico. Estos indicadores incluyen riachuelos (canalillos), patrones de escurrimiento, pedestales y terracetas, suelo desnudo, quebradas (carcavas), erosión eólica y áreas de deposición, movimiento de mantillo, resistencia del suelo a la erosión, degradación o perdida de la superficie del suelo, composición vegetal con relación a la infiltración, compactación del suelo, grupos vegetales funcionales y estructurales, mortalidad vegetal, cantidad de mantillo, producción anual, plantas invasivas, y capacidad de reproducción. En este informe, detallamos el desarrollo y evolución de esta técnica. También introducimos una tabla de datos de referencia ecológica modificada que documenta la presencia esperada y la cantidad de cada indicador en el sitio ecológico. En adición, repasamos las aplicaciones apropiadas para esta técnica y clarificamos las diferencias entre evaluación y monitoreo que nos llevaron a recomendar que esta técnica deberá ser utilizada para evaluación de un punto en el tiempo, y no para un monitoreo temporal de el estado de agostaderos. Por ultimo, recomendamos un mecanismo para adaptar y modificar esta técnica para reflejar mejoramientos y entendimiento de los procesos de ecosistemas. Soportamos la necesidad de medidas cuantitativas para el monitoreo de salud de los agostaderos, por lo cual proponemos algunas medidas que creemos que pueden tomarse en cuenta para algunos de los 17 indicadores.

Rangeland assessments in the United States over the past century have relied heavily on the Clementsian view of plant succession that plant communities progress or regress along predictable courses of defined communities in response to changes in disturbance or environmental regimes, including grazing and precipitation (Clements 1920, Dyksterhuis 1949). Rangeland scientists and managers have increasingly questioned the appropriateness 
of this model for making 1 type of rangeland assessment, rangeland condition (Westoby et al. 1989a, 1989b, Friedel 1991, Laycock 1991, Svejcar and Brown 1991). Two panels of experts, National Research Council (NRC 1994) and the Society for Range Management Task Group on Unity in Concepts and Terminology Committee (SRM Task Group 1'995), suggested alternative approaches for evaluating rangeland status that relied on factors other than the traditional rangeland condition classification and on similarity of plant species composition to a single climax community. The NRC (1994) experts advocated the evaluation of multiple indicators to assess a site's degree of soil stability and watershed function, integrity of nutrient cycles and energy flow, and presence of functioning recovery mechanisms. The SRM Task Group (1995) recommended that new assessments focus primarily on the soil stability of a site. The Task Group recommended and the SRM adopted the following: (1) that evaluations of a site be based on the expected capability for that land unit (the ecological site) to support a natural range of potential plant communities; (2) that each potential plant community be evaluated for its ability to protect the site from accelerated erosion; and (3) that managers develop objectives for land uses and manage the land to achieve or maintain a desired plant community that protects the site against accelerated erosion.

The U. S. Department of the Interior (USDI), Bureau of Land Management (BLM) and the U. S. Department of Agriculture (USDA), Natural Resources Conservation Service (NRCS) expressed a need for a rapid technique that provides an initial assessment of rangeland health based on a workable set of criteria from a combination of the NRC (1994) and SRM Task Group (1995) reports. These agencies were not seeking a monitoring technique (as defined by SRM Glossary Update Task Group 1998) to determine if their management objectives had been met over time or if significant progress had been made toward meeting these objectives. Rather, they sought a moment-intime assessment that would be equally effective in estimating the status of most rangeland communities (i.e., from tropical grasslands and coastal marshes to desert and tundra ecosystems) within the United States.

We address 4 objectives in this paper. First, we provide an overview of a technique that satisfies the NRCS/BLM criteria (Pellant et al. 2000). Second, we describe the approach used to develop this technique and introduce an improved technique for developing reference conditions for ecological sites. Third, we define the intended applications of the technique and explain the why we believe this technique may be used to provide a moment-in-time assessment of rangeland health, but not to temporally monitor rangelands. Fourth, we describe a mechanism for adapting the technique for different ecosystems and for ensuring that the technique will continue to reflect improvements in understanding of ecosystem processes.

\section{Rangeland Health}

We have chosen to use a definition of rangeland health developed by an ad hoc interagency committee (USDA, NRCS 1997). Rangeland health is the degree to which the integrity of the soil, vegetation, water and air as well as the ecological processes of the rangeland ecosystem are balanced and sustained. Integrity is defined as the maintenance of the functional attributes characteristic of a locale, including normal variability. Although there are a number of problems associated with applying the term "health " to natural ecosystems (Wicklum and Davies 1995, Lackey 1998, Rapport et al. 1998, Smith 1999), we elected to retain it. The NRC (1994) report used the term in the title of its publication. Concurrently, the public has begun to accept this term and to associate it with the status of ecological systems. With Rangeland Reform in 1994, the BLM began developing standards for rangeland health and guidelines for livestock grazing management on BLM rangelands with the assistance of Resource Advisory Councils (USDI, BLM 1994). Although these standards and guidelines differ for each state, they all incorporate language that relates to ecosystem health and have become the BLM policy for assessing public land health and for obtaining or maintaining ecological structure and function on BLM-managed lands (USDI, BLM 2001). Similarly, the NRCS has incorporated the term rangeland health into their latest addition of the National Range and Pasture Handbook and into the inventory phase of the conservation planning process that they conduct with private landowners (USDA, NRCS 1997). By retaining and defining rangeland health, we maintain a connection to the NRC report, to BLM's standards and guidelines for managing rangelands, and to NRCS National Range and Pasture Handbook.

\section{Historical Development}

Background. In the mid 1990's, several groups simultaneously advocated that all U.S. governmental agencies with responsibility for managing or reporting rangeland status should coordinate a national assessment of rangelands using common techniques and designs (West et al. 1994, NRC 1994, SRM Task Group 1995). Two of these reports (NRC 1994, SRM Task Group 1995) recommended the development of quantitative techniques for assessing ecosystem status, but both also noted that researchers would need to develop new and efficient techniques to measure many indicators of ecosystem status.

The NRC (1994) and SRM Task Group (1995) also recommended that assessments be used to classify and compare similar combinations of soils and climate that have the capacity to support ecosystems with similar plant communities and production (e.g., ecological sites). New ecological site descriptions (USDA, NRCS 1997), which are in the process of being developed, recognize and portray the multiplicity of vegetation states and transitions among states that are expected with natural or human-induced changes (Westoby et al. 1989a, 1989b, Stringham et al. 2001). These descriptions also use the threshold concept to describe unidirectional changes in ecosystem structure and ecosystem functional processes. When these thresholds are crossed, recovery to original ecosystem states is difficult (Laycock 1991, Friedel 1991, SRM Task Group 1995). When possible, ecosystem assessments should strive to incorporate these concepts as research results refine our understanding of states, transitions and thresholds.

In 1997, agency leaders for the BLM, NRCS, and the USDA Forest Service signed a Memorandum of Understanding (interagency MOU group) that formed a committee responsible for overseeing the development of a common national rangeland assessment technique. This committee is pursuing the development of quantitative assessment indicators and protocols.

While quantitative national assessment techniques are being developed, the BLM and NRCS identified a need for a rapid assessment technique that could provide a preliminary assessment of rangeland health at the management unit or lower level. Additionally, the technique could provide a communication tool with stakeholders regarding the status of ecosystem properties and processes. 
Approach used to develop the technique. In 1995, the NRCS and BLM began development of qualitative techniques for the assessment of rangeland health using the NRC (1994) and SRM Task Group (1995) recommendations as a starting point. These efforts resulted in the development of 2 similar protocols. The first 2 versions of this technique were developed separately by the BLM (Pellant 1996) and NRCS (USDA, NRCS 1997). These versions were similar, but not identical. In 1997, we integrated these versions and began a coordinated effort to evaluate each indicator based on the scientific literature and field tests in rangeland ecosystems throughout the United States. Indicators that were not supported by the literature, that could not be consistently applied or interpreted, or that were not sensitive to changes in ecosystem structure or function across a wide variety of ecosystems, were modified, replaced or discarded. For example, repeatability among observers varied using the BLM version that contained only 3 rating categories (properly functioning, functioning at risk, and non-functioning) for 18 indicators divided among a biotic and a physical attribute (Rasmussen et al. 1999). In response, we adjusted the rating categories to 5 , the level used in the NRCS version of the technique.

This iterative process involved approximately 500 people participating in over 16 training or testing sessions in 10 states covering 9 of the 36 ecosystem provinces of the humid, temperate and dry domains in the 48 contiguous states in the United States (Bailey et al. 1994). Participants included scientists (federal and university), federal, state, and tribal land managers, ranchers and members of conservation organizations. Over 20 scientists, 25 BLM and NRCS resource specialists, 35 consultants from the Association of Rangeland Consultants, and members of the Western Coordinating Committee on Rangeland Ecological Research and Assessment (WCC-40) reviewed and criticized the final draft of the technique. The technique and the document (Pellant et al. 2000) were improved by incorporating modifications suggested by these peers. For example, training participants found it difficult to provide a single assessment of rangeland health for an evaluation area and that they wanted to be able to generate information relevant to specific attributes. In response, we modified the technique to provide separate ratings for each of the 3 attributes and to eliminate any reference to a single rating of overall status.

\section{Description of the Technique (Methods)}

Overview. The technique involves evaluating all locations using the same minimum set of 17 qualitative indicators relative to their potential within an ecological site. We use the Society for Range Management (SRM Glossary Update Task Group 1998) definition of an ecological site being "a kind of land with specific physical characteristics which differs from other kinds of land in its ability to produce distinctive kinds and amounts of vegetation and in its response to management." Site potential for each indicator is defined by that indicator's presence and range of amount in resistant and resilient plant community phases that maximize retention of soil. These may be determined by examining a range of reference areas that describe these phases or they may be defined in or inferred from the ecological site description. Ecological site descriptions describe soil associations (as defined by the Soil Science Society of America 1997) and their physical, hydrological and biological characteristics that produce distinctive kinds and amounts of vegetation. The amount of information included in ecological site descriptions varies depending on when the description was written. Early descriptions, originally called range site descriptions, contained basic descriptions of soils and vegetation. Ecological site descriptions written or revised since 1997 contain additional detail on the variation in plant composition, cover and production for the dynamic set of vegetation states and on hydrologic and soil stability characteristics of the ecological site. The NRCS has committed to a program of revising all previously written range site and ecological site descriptions into this new format (Pers. Comm. G. Peacock, NRCS Grazing Lands Technology Institute, Fort Worth Tex.). All currently approved ecological site descriptions are available at local NRCS offices. In addition, they will be available on the Internet at the PLANTS database homepage (USDA, NRCS 2001) under the Ecological Site Information System (ESIS) heading. If neither reference areas nor an ecological site description exist, then a group of soil and plant experts should define and document their expectations for each of these indicators using their knowledge and data about similar soils and plant communities.

Three overlapping subsets of indicators are used to assess 3 attributes of the site: soil and site stability, hydrologic function, and biotic integrity. We use the term attribute to describe an ecosystem component that cannot be directly measured, but can be approximated by a set of observable indicators of the component. The assessment of these 3 attributes is the final product of the technique. In the remainder of this section, we describe attributes and indicators, outline the technique that is used to evaluate each indicator relative to its potential for a particular site. We include a new method for documenting reference conditions for each indicator and define how the 3 attributes are evaluated based on a combination of indicators to arrive at an assessment of the status of each attribute.

Attributes. Both the SRM Task Group (1995) and the NRC (1994) reports suggested a single rating for the site assessment. The SRM Task Group (1995) emphasized soil conservation in their hypothetical quantitative approach. They proposed the development of a Site Conservation Rating (SCR), "an assessment of the protection afforded a site by the current vegetation against loss of potential." They also proposed that a Site Conservation Threshold (SCT), "the kind, amount, and/or pattern of vegetation needed as a minimum on a given site to prevent accelerated erosion," would provide a mechanism for categorizing a site as "satisfactory or sustainable" or "unsatisfactory or unsustainable." Although this Task Group proposed this new approach for evaluating lands, they clearly stated that criteria for evaluating the SCR and SCT should be objective and quantitative enough to serve as monitoring parameters for assessing the trend in the SCR. However, these criteria "will have to be worked out by research and professional judgment for each ecological site" (SRM Task Group 1995). To our knowledge, few studies have attempted to develop or test quantitative criteria for a SCR (Watters et al. 1996) whereas some development has begun for some indicators of forest and rangeland health or sustainability (de Soyza et al. 1997, 2000, Weltz et al. 2000, Woodley et al. 2000, Herrick et al. 2002).

The NRC (1994) suggested classifying lands into 3 categories using soil and ecological processes as basic elements of site production: (1) those lands that remain above an early warning line where the land produces at its potential for commodities and other values; (2) those that fall below this early warning line and have a reduced ability to produce commodities and support other values, but where this reduction can be reversed through man- 
Table 1. Standard indicators included in the rangeland health protocol, attributes to which each indicator applies, and publications used to develop the descriptors and interpretations for each indicator.

Indicators and brief descriptions of characteristics for evaluating the indicator

\begin{tabular}{lll}
\multicolumn{3}{c}{ Attributes } \\
\hline Soil and & Hydrologic & Biotic \\
Site & Function & Integrity \\
Stability & & \\
\hline
\end{tabular}

1. Rills - the frequency and spatial distribution of linear erosional rivulets.

2. Water Flow Patterns - the amount and distribution of overland flow paths that are identified by litter distribution and visual evidence of soil and gravel movement.

3. Pedestals and/or Terracettes - the frequency and distribution of rocks or plants where soil has been eroded from their base (pedestals) or areas of soil deposition behind obstacles.

4. Bare Ground - size and connectivity among areas of soil not protected by vegetation, biological soil crusts, litter, standing dead vegetation, gravel or rocks.

5. Gullies -amount of channels cut into the soil and the amount and distribution of vegetation in the channel.

6. Wind Scoured, Blowouts and/or Deposition Areas frequency of areas where soil is removed from under physical or biological soil crust or around vegetation OR frequency of accumulation areas of soil associated with large structural objects, often woody plants.

7. Litter Movement - frequency and size of displaced litter by wind and overland flow of water.

8. Soil Surface Resistance to Erosion - ability of soils to resist erosion through the incorporation of organic material into soil aggregates. It is evaluated by using a modified slake test.

9. Soil Surface Loss or Degradation - frequency and size of areas missing all or portions of the upper soil horizons that normally contain the majority of organic material of the site.

10. Plant Community Composition \& Distribution Relative to Infiltration \& Runoff - the community composition or distribution of species that restrict the infiltration of water on the site.

11. Compaction Layer - thickness and distribution of the structure of the soil near the soil surface $(=<15 \mathrm{~cm})$

12. Functional/Structural Groups - the number of groups, the number of species within groups, or the rank of order of dominance of groups.

13. Plant Mortality/Decadence - frequency of dead or moribund (dying) plants

14. Litter Amount - deviation in the amount of litter.

15. Annual Abroveground Production - amount relative to the potential for that year based upon the climate.

16. Invasive Plants - abundance and distribution of invasive plants regardless if they are noxious weeds, exotic species, or native plants whose dominance greatly exceeds that expected at the ecological site.

17. Reproductive Capability of Perennial Plants - evidence of the inflorescences or of vegetative tiller production relative to the potential based upon the current climate.

$\mathrm{X}$

$\mathrm{X} \quad \mathrm{X}$

$\mathrm{X} \quad \mathrm{X}$

$\mathrm{X} \quad \mathrm{X}$

Relevant Literature

Quansah 1985, Morgan and Davidson 1986, Bryan 1987

Morgan and Davidson 1986, Tiscareño Lopez et al. 1993

Anderson 1974, Morgan and Davidson 1986, Satterlund and Adams 1992, Hudson 1993

Smith and Wischmeier 1962, Anderson 1974, Gould 1982, Morgan and Davidson 1986, Benkobi et al. 1993 , Blackburn and Pierson 1994, Pierson et al. 1994. Spaeth et al. 1994, Gutierrez and Hernandez 1996, Puigdefábregas and Sánchez 1996, Weltz et al. 1998, Cerda 1999

Anderson 1974, Morgan and Davidson 1986, Martin and Morton 1993

Chepil 1945, Chepil and Woodruff 1963, Anderson 1974, Gillette et al. 1974, Gillette and Walker 1977, Gibbens et al. 1983, Hennessy et al. 1983, Hagen 1984, Hennessy et al. 1986, Morgan and Davidson 1986, Pye 1987

$\mathrm{X}$

X $\quad X$

X

$\mathrm{X}$

Thurow et al. 1988

Bond and Harris 1964, Belnap and Gardner 1993, Blackburn et al. 1992, Morgan and Davidson 1986,

Goff et al. 1993, Blackburn and Pierson 1994, Fryrear et al. 1994, Pierson et al. 1994, Morgan et al. 1997, Belnap and Gillette 1998, Herrick et al. 2001

X $\quad X \quad X$

Hennessy et al. 1986, Warren et al. 1986, Satterlund and Adams 1992, O'Hara et al. 1993, Karlen and Stott 1994, Wood et al. 1997, Davenport et al. 1998, Dormaar and Willms 1998

X Blackburn 1975, Wood and Blackburn 1984,

Johnson and Gordon 1988, Thurow et al. 1988,

Blackburn and Wood 1990, Schlesinger et al. 1990, Blackburn et al. 1992

$\mathrm{X} \quad \mathrm{X} \quad \mathrm{X}$

Barnes et al. 1971, Webb and Wilshire 1983, Willat and Pullar 1983, Cole 1985, Blake and Hartge 1986, Warren et al. 1986, Wallace 1987, Thurow et al. 1988, Hassink et al. 1993, Larson and Pierce 1993, Chanasyk and Naeth 1995, Hillel 1998

X Chapin 1993, Dawson and Chapin 1993, Solbrig et al. 1996, Tilman et al. 1997

X Stoddard et al. 1975, Pyke 1995,

$\mathrm{X} \quad \mathrm{X}$

Thurow et al. 1988, Whitford 1988, Whitford 1996, Hester et al. 1997

X Cooper 1975, Whittaker 1975, Rickard and Rogers 1988, Tilman and Downing 1994

X Lacey et al. 1990, Olson 1999, Stohlgren et al. 1999

$\mathrm{X}$
Hanson and Stoddard 1940, Mueggler 1975, Harper 1977, White 1979 
Table 2. The 6 steps of the Interpreting Indicators of Rangeland Health (Pellant et al. 2000) are summarized along with the location (evaluation or reference area) where the step is completed, and the recommended worksheets (found in Pellant et al. 2000) that are used when completing each step.

\begin{tabular}{|c|c|c|c|}
\hline Step & Description & Location & Recommended worksheets \\
\hline$\overline{1}$ & $\begin{array}{l}\text { Identify the evaluation area } \\
\text { and verify soils and ecological } \\
\text { site for the area }\end{array}$ & Evaluation Area & $\begin{array}{l}\text { 1. Rangeland Health } \\
\text { Evaluation Summary, Part } 1\end{array}$ \\
\hline 2 & $\begin{array}{l}\text { Develop expected indicator } \\
\text { ranges for the ecological site. } \\
\text { Visually familiarize yourself } \\
\text { with the } 17 \text { indicators at an } \\
\text { Ecological Reference Area and } \\
\text { rate the reference area against } \\
\text { the Ecological Reference } \\
\text { Worksheet }\end{array}$ & $\begin{array}{l}\text { In the office and } \\
\text { at the Ecological } \\
\text { Reference Area }\end{array}$ & $\begin{array}{l}\text { 1. New Ecological Reference } \\
\text { Worksheet (Table 3) } \\
\text { 2. Cover } \\
\text { 3. Species Dominance } \\
\text { 4. Functional/Structural } \\
\text { Groups (Potential } \\
\text { Dominance) }\end{array}$ \\
\hline 3 & $\begin{array}{l}\text { Review or modify descriptors of } \\
\text { indicators }\end{array}$ & $\begin{array}{c}\text { Ecological } \\
\text { Reference Area }\end{array}$ & $\begin{array}{l}\text { 1. Rangeland Health Indicator } \\
\text { Evaluation Matrix (Table 4) }\end{array}$ \\
\hline 4 & $\begin{array}{l}\text { Characterize the vegetation } \\
\text { found at the evaluation area }\end{array}$ & Evaluation Area & $\begin{array}{l}\text { 1. Cover } \\
\text { 2. Species Dominance } \\
\text { 3. Functional/Structural Groups } \\
\text { (Actual Dominance) }\end{array}$ \\
\hline 5 & Rate the 17 indicators & Evaluation Area & $\begin{array}{l}\text { 1. Rangeland Health Evaluation } \\
\text { Summary, Part } 2 \text { (Table 5) } \\
\text { 2. Use Rangeland Health } \\
\text { Indicator Evaluation Matrix } \\
\text { (Table 4) }\end{array}$ \\
\hline 6 & $\begin{array}{l}\text { Determine functional status of } \\
\text { the rangeland health attributes }\end{array}$ & Evaluation Area & $\begin{array}{l}\text { 1. Rangeland Health Evaluation } \\
\text { Summary, Part } 3 \text { (Table 6) }\end{array}$ \\
\hline
\end{tabular}

agement changes; and (3) those sites with substantial reductions in commodities and values where management changes are not likely to reverse this reduction. They proposed that criteria for rangeland health be defined using multiple indicators in 3 major areas: (1) soil stability and watershed function; (2) the integrity of nutrient cycles and energy flow; and (3) the presence of functioning recovery mechanisms. Although they proposed these criteria, they recognized the lack of quantitative procedures that could be used efficiently and economically in assessments of large amounts of rangelands. They advocated the need for research to develop such quantitative approaches, but in lieu of such techniques, they suggested a series of indicators that could be qualitatively evaluated.

Although a single rating of a site's status is intuitively appealing, we discovered early in the development process of this current approach that some sites might have attributes of ecosystem status that were operating properly while other attributes were not. Initially, we began to look for indicators of nutrient cycling, energy flow and recovery mechanisms that observers could evaluate, but direct linkages between observable quantitative or qualitative measures of these processes were not easy to determine. By blending the NRC and the SRM Task Group approaches and by using an iterative process of field tests and peer reviews by land managers and scientists, we identified 3 attributes of ecosystem status that can be evaluated using multiple indicators:

Soil or Site Stability - The capacity of the site to limit redistribution and loss of soil resources (including nutrients and organic matter) by wind or water;

Hydrologic Function - The capacity of the site to capture, store and safely release water from rainfall, run-on and snowmelt (where relevant), to resist a reduction in this capacity and to recover this capacity following degradation;

Integrity of the Biotic Community The capacity of the site to support characteristic functional and structural communities in the context of normal variability and to resist loss of this function and structure caused by disturbance, and to recover following each disturbance.

Indicators. We have selected indicators to represent components of attributes that are difficult to measure directly. This use of indicators is similar to the approach used by others in selecting forest or rangeland indicators (Breckenridge et al. 1995, de Soyza et al. 1997, 2000, Whitford et al. 1998, Woodley et al. 2000). We define indicators as observable components of an ecosystem that are related to 1 or more attributes, are easily evaluated, and used in combination with other indicators as an index of the status of that attribute. Each indicator at an evaluation area is assigned to 1 of 5 categories based on its departure from what is expected for that ecological site. The expectation for the ecological site should be derived from the soil survey, the ecological site description or, as a last resort, from expert opinion. Evaluators rate a site using 5 categories that describe a gradient for each indicator associated with each attribute. Indicators were selected if we could provide affirmative answers to 2 successive questions. (1) Did peerreviewed literature exist to support the association of this indicator with its attribute? (2) Could experienced land managers understand and consistently provide a visual assessment of this indicator?

Currently, we have included 17 indicators for rating the 3 attributes (Table 1). Additional information on the scientific basis for each indicator is included in an interagency technical reference (Pellant et al. 2000). Indicators can be associated with single attributes, such as litter movement's association with hydrologic function and invasive plants' association with biological integrity. Other indicators are associated with 2 or all 3 attributes (Table $1)$. We recognize that some of these indicators might be related to additional attributes, but we believe the associations that we have selected are the strongest or the best supported by the literature.

Procedure. To rate the 3 attributes at an evaluation area, an evaluator must complete a 6-step process (Pellant et al. 2000, Table 2). Step 1 requires that evaluators visit an evaluation area to verify the soil and the ecological site of the area. Evaluation areas may be specific sites of concern within a management unit (e.g., a pasture, watershed, allotment or management area) or they may be a representative subsample of strata within a larger management unit (see Intended Applications). Evaluation areas should be within a specific landscape position, include the natural variability of the ecological site, but remain sufficiently small (approximately 0.4 to 2.0 ha or 1 to $5 \mathrm{ac}$ ), so that evaluators can easily walk throughout the area and observe the variation in the plant species composition and soil surface features. Since assessments will be made relative to the ecological site description or ecological reference areas on the same ecological site, evaluators must be certain of the evaluation area's landscape position and soils (same ecological site). The eco- 
Table 3. Example of an Ecological Reference Worksheet developed for the Limy Ecological Site Description (italics) in the Southern Desert 4 subarea of Southern Desertic Basins, Plains and Mountains Major Land Resource Area (MLRA 42) in New Mexico. This example is based on the Natural Resources Conservation Service Ecological Site Description, unpublished data, and collective knowledge of J. Christensen, B. Call, B. Bestelmeyer, R. Placker, D. Trujillo, L. Hauser, D. Coalson, P. Smith, and J. Herrick.

Indicators. For each indicator, describe the potential for the site. Where possible, (1) use numbers, (2) include expected range of values for poor-good years, when appropriate \& (3) cite data. Continue descriptions on separate sheet.

1. Number and extent of rills: None.

2. Presence of water flow patterns: None, except following extremely high intensity storms, when short (less than $1 \mathrm{~m}$ ) flow patterns may appear.

3. Number and height of erosional pedestals or terracettes: None.

4. Bare ground from Ecological Site Description or other studies (rock, litter, lichen, moss, plant canopy are not bare ground): 20 - $30 \%$ bare ground; bare patches should be less than 8-10 inch diameter; occasional 12 inch patches associated with shrubs. Larger bare patches also associated with ant mounds and rodent disturbances.

5. Number of gullies and erosion associated with gullies: None.

6. Extent of wind scoured, blowouts and/or depositional areas: None.

7. Amount of litter movement (describe size and distance expected to travel): Minimal and short, associated with water flow patterns following extremely high intensity storms. Litter also may be moved during intense wind storms.

8. Soil surface (top few $\mathbf{m m}$ ) resistance to erosion (stability values are averages - most sites will show a range of values): Stability class (Herrick et al. 2001) anticipated to be 5-6 at surface and subsurface under vegetation and 4-5 at surface and subsurface in the interspaces. These values need verification at reference sites.

9. Soil surface structure and SOM content (include type and strength of structure, and A-horizon color and thickness): 2-4 inch dark brown A horizon with medium granular structure (Otero County Armesa series description refers to platy structure; probably not from a true reference site).

10. Effect of plant community composition (relative proportion of different functional groups) $\&$ spatial distribution on infiltration $\&$ runoff: High grass canopy and basal cover and small gaps between plants should reduce raindrop impact and slow overland flow, providing increased time for infiltration to occur. High root density of blue grama can limit infiltration. The more herbaceous vegetation on this site will result in less rain necessary to sustain this site because more water is retained.

11. Presence and thickness of compaction layer (usually none; describe soil profile features which may be mistaken for compaction on this site): None

12. Functional/Structural Groups (list in order of descending dominance by above-ground weight using symbols: $>>,>,=$ to indicate much greater than, greater than, and equal to): Blue grama $>$ Black grama $>$ warm season bunchgrasses $>$ Yucca $=$ shrubs $>>$ sub-shrubs $=$ succulents; Forbs $0-8$ $\%$ depending on the year.

13. Amount of plant mortality and decadence (include which functional groups are expected to show mortality or decadence): Grasses will nearly always show some mortality and decadence.

14. Average percent litter cover (_ $\%$ ) and depth (__ inches). $20-25 \%$ litter cover and 0.25 inch depth.

15. Expected annual production (this is TOTAL above-ground production, not just forage production)

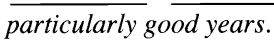

16. Potential invasive (including noxious) species (native and non-native). List species which characterize degraded states and which, after a threshold is crossed, "can and often do continue to increase regardless of the management of the site and may eventually dominate the site": Possibly creosote bush which is an invader on similar ecological sites; snakeweed is cyclical, so not regarded as an invasive plant on this ecological site.

17. Perennial plant reproductive capability: all species should be capable of reproducing.

logical site will encompass the normal range of variation of successional communities (community phases) with reversible transitions (community pathways) within an ecological state (as defined by Stringham et al. 2001). Since some evaluation areas have crossed thresholds (irreversible transitions) to another ecological state, evaluators must recognize that soils, not plant communities, will be the best aid in identifying the ecological site.

To document soils at evaluation and reference areas, evaluators document the presence and depths of the appropriate diagnostic soil horizons found in each area and provide the corresponding information from the soil survey or ecological site description in the first portion of the Rangeland Health Evaluation Summary (Pellant et al. 2000) and the Ecological Reference Worksheets (Table 3). Evaluators also document the area's location, parent material, slope gradient and topographic position on these same worksheets. Recent weather conditions and cycles should be reported along with disturbances or off-area influences that might affect the assessment.

The objective of the next 2 steps is to define the expected status of each indicator on a healthy site. This process involves examination, and in some cases modification, of the descriptor narratives for the 5 categories for each indicator. We have prepared several worksheets to assist in this process (Table 2).

During Step 2, each indicator is described on a new portion of the ecological reference worksheet (Table 3) developed after the publication of Version 3.0 (Pellant et al. 2000). We have found that the most effective way to develop these reference worksheets is to assemble a diverse group of experts regarding the ecological site. Individuals should be included who have extensive, long-term knowledge of the ecological site, in addition to rangeland professionals who understand general soil-climate-vegetation relationships and the relevant literature. These individuals should use all available sources of information, particularly ecological site descriptions and data from potential reference sites. The process is extremely useful for identifying knowledge gaps that require additional research and for helping diverse groups to improve their collective understanding of relationships between soils, vegetation and hydrology. This worksheet is valuable for 3 reasons. First, it is more convenient and therefore more likely to be referred to in the field than a complete ecological site description. Second, the completed reference worksheet can be used to facilitate the development of consensus about each indicator's presence and amount on an ecological site, particularly when no ecological site description is available. Third, and most important, it can increase the consistency with which the method is applied by clarifying the standard that is used to evaluate each indicator. A related use is to compare the description to the "None-Slight" default descriptor in Pellant 
Table 4. An example of a series of default descriptions for the bare ground indicator and a hypothetical revision of the descriptions for an ecological site (from Pellant et al. 2000).

\begin{tabular}{|c|c|c|c|c|c|}
\hline \multirow{2}{*}{ Indicator } & \multicolumn{5}{|c|}{ Degree of Departure from Ecological Site Description and/or Reference Area(s) } \\
\hline & Extreme & Moderate to Extreme & Moderate & Slight to Moderate & None to Slight \\
\hline $\begin{array}{l}\text { 4. Bare Ground } \\
\text { (Default description) }\end{array}$ & $\begin{array}{l}\text { Much higher than } \\
\text { expected for the site. } \\
\text { Bare areas are large } \\
\text { and generally } \\
\text { connected. }\end{array}$ & $\begin{array}{l}\text { Moderately higher } \\
\text { than expected for the } \\
\text { site. Bare areas are } \\
\text { large and occasionally } \\
\text { connected. }\end{array}$ & $\begin{array}{l}\text { Moderately to slightly } \\
\text { higher than expected } \\
\text { for the site. Bare } \\
\text { areas are of moderate } \\
\text { size and sporadically } \\
\text { connected. }\end{array}$ & $\begin{array}{l}\text { Slightly higher than } \\
\text { expected for the site. } \\
\text { Bare areas are small } \\
\text { and rarely connected. }\end{array}$ & $\begin{array}{l}\text { Amount and size of } \\
\text { bare areas matches } \\
\text { that expected for the } \\
\text { site. }\end{array}$ \\
\hline $\begin{array}{l}\text { Bare Ground } \\
\text { (Revised description) }\end{array}$ & $\begin{array}{l}\text { Much higher than } \\
\text { expected for the site. } \\
\text { Bare areas are } \\
\text { extensive with little } \\
\text { ground cover. }\end{array}$ & $\begin{array}{l}\text { Moderately higher } \\
\text { than expected for the } \\
\text { site. Bare areas are } \\
\text { very large and usually } \\
\text { connected. }\end{array}$ & $\begin{array}{l}\text { Moderately to slightly } \\
\text { higher than expected } \\
\text { for the site. Bare } \\
\text { areas are large and } \\
\text { usually connected. }\end{array}$ & $\begin{array}{l}\text { Slightly higher than } \\
\text { expected for the site. } \\
\text { Bare areas are of } \\
\text { moderate size and } \\
\text { usually connected. }\end{array}$ & $\begin{array}{l}\text { Same as default } \\
\text { descriptor }\end{array}$ \\
\hline
\end{tabular}

et al. (2000) in order to highlight those indicators that are likely to require descriptor revisions.

Once the reference worksheet is developed, evaluators should attempt to locate and visit ecological reference areas (ERA). The ERA's are landscape units that provide visual representations of the characteristics and variability in the ecological site description. These areas do not need to be pristine, historically unused lands (e.g., climax plant communities or relict areas). This concept is similar to that proposed by the Western Regional Coordinating Committee-40 on Rangeland Ecological Research and Assessment of using well-managed rangelands and appropriate relict areas as benchmarks for assessments (West et al. 1994). Since revised ecological site descriptions will include the range of vegetation communities that may exist on an ecological site, the ERA should represent the expected state that would result from natural disturbances such as fire or drought. A single reference area will represent 1 spatial point and temporal moment of this range of variation for that ecological site. Thus, an ERA will represent a single community phase within the ecological state for that ecological site. Evaluators should recognize that vegetation composition within an ecological state may change over time through reversible transitions and should account for this in their interpretation of the ecological site (Stringham et al. 2001).

It is also important to avoid areas that are more productive than anticipated based on the site description, particularly where there is no current or historical explanation for the high productivity. Significantly higher productivity is often due to soil or topographic differences, including differences within a single soil series. These differences can also affect the resistance of the site to degradation and recovery. Evaluators should check texture, depth and topographic position, particularly in landscapes where significant runoff or run-on occurs.

To assist evaluators in identification of appropriate ERAs and comparisons with the evaluation area(s), we prepared another set of worksheets (Table 2) to lead them through the process of observation, categorization and documentation of the appropriate information. In the canopy and ground cover worksheet, evaluators estimate broad cover classes for vegetation life forms and ground cover parameters. Species dominance based on cover or biomass is estimated for each major life form group and for the whole site. In the structural and functional groups worksheet, species are placed into structural and functional groups and each group is placed into a dominance class based on the groups relative production or cover. These worksheets assist evaluators to visualize plant species, soil, and hydrological indicators under current weather conditions in this locale. Information from each of these worksheets is used together with additional observations to verify that an ecological reference area agrees with the ecological reference worksheet where soils and the ecological site are verified and where the presence and status of each of the 17 indicators is documented. Photographs, and if possible quantitative data, of ecological reference areas are also recommended to aid in subsequent assessments of similar landscape units.

In some locations and ecological sites, finding an ERA that fits within the range of variation of the ecological site descrip- tion may be difficult because of site degradation. In those cases, evaluators may elect to only use the ecological site description as the standard of comparison or may elect to use a site as an ERA with limitations. It is still useful, however, to complete worksheets based on the ecological site descriptions and knowledge from local experts.

In Step 3, evaluators compare the series of default narrative descriptions for rating each indicator to the ecological site description and the ERA to determine if default descriptions are adequate for describing the indicator in the ecological site or if a modified description should be written. Each of the 17 indicators has a separate default set of narrative descriptions similar to the default description for bare ground shown in Table 4. All of the narrative descriptors rate indicators at the evaluation area based on that location's degree of departure from ecological site description. Below each default narrative, a blank space is provided for evaluators to write a revised description. These revised descriptions can be written and used immediately, provided that the change is clearly documented in reports or recommendations made based on the assessment, and that consistency can be maintained among assessments made in a particular area or for a particular project. When revised descriptions are necessary, they should be submitted to the NRCS State Rangeland Management Specialist. Each ecological site will have one set of descriptions. This person along with other interested people will discuss and consider the inclusion of the proposed narrative revision in updated ecological site descriptions using accepted NRCS protocols for revisions. Eventually, we hope that each 
Table 5. A hypothetical example of a completed Rangeland Health Evaluation Summary Worksheet, part 2 used in the rangeland health assessment for a site. Letters S, W and B under the Attribute column refer to Soil, Water, and Biology and indicate association of the indicator with the respective attributes, Soil or Site Stability, Hydrologic Function, or Biological Integrity. The comments section is used to help evaluators document their rationale for the specific rating of selected indicators.

\begin{tabular}{|c|c|c|c|c|c|c|}
\hline \multirow[b]{2}{*}{ Attribute } & \multirow[b]{2}{*}{ Indicators } & \multicolumn{5}{|c|}{ Departure from Ecological Site Description/Reference Area(s) } \\
\hline & & Extreme & $\begin{array}{l}\text { Moderate to } \\
\text { Extreme }\end{array}$ & Moderate & $\begin{array}{l}\text { Slight to } \\
\text { Moderate }\end{array}$ & None to Slight \\
\hline $\mathrm{S}, \mathrm{W}$ & 1. Rills & & & & $\sqrt{ }$ & \\
\hline \multicolumn{7}{|l|}{ Comments } \\
\hline $\mathrm{S}, \mathrm{W}$ & 2. Water Flow Patterns & & & & $\sqrt{ }$ & \\
\hline \multicolumn{7}{|l|}{ Comments } \\
\hline $\mathrm{S}, \mathrm{W}$ & 3. Pedestals and/or Terracettes & & & $\sqrt{ }$ & & \\
\hline \multicolumn{7}{|c|}{ Comments - Several plants along flowpaths have roots exposed, but site is not prone to frost heaving } \\
\hline $\mathrm{S}, \mathrm{W}$ & 4. Bare Ground & & & & $\sqrt{ }$ & \\
\hline \multicolumn{7}{|l|}{ Comments } \\
\hline $\mathrm{S}, \mathrm{W}$ & 5. Gullies & & & & $\sqrt{ }$ & \\
\hline \multicolumn{7}{|c|}{ Comments - One gully visible, vegetation in bottom and on sides; no evidence of headcuts } \\
\hline $\mathrm{S}$ & $\begin{array}{l}\text { 6. Wind Scoured, Blowouts and/or Deposition } \\
\text { Areas }\end{array}$ & & & & & $\sqrt{ }$ \\
\hline \multicolumn{7}{|c|}{ Comments } \\
\hline W & 7. Litter Movement & & & & & $\sqrt{ }$ \\
\hline \multicolumn{7}{|l|}{ Comments } \\
\hline $\mathrm{S}, \mathrm{B}, \mathrm{W}$ & 8. Soil Surface Resistance to Erosion & & & $\sqrt{ }$ & & \\
\hline \multicolumn{7}{|c|}{ Comments - The majority of soil samples from under canopies of plants tending to fall apart when placed in water } \\
\hline $\mathrm{S}, \mathrm{B}, \mathrm{W}$ & 9. Soil Surface Loss or Degradation & & & $\sqrt{ }$ & & \\
\hline \multicolumn{7}{|c|}{ Comments - A-horizon missing in interspaces; present under shrubs or larger grasses } \\
\hline W & $\begin{array}{l}\text { 10. Plant Community Composition \& Distribution } \\
\text { Relative to Infiltration \& Runoff }\end{array}$ & & & $\sqrt{ }$ & & \\
\hline \multicolumn{7}{|c|}{ Comments } \\
\hline $\mathrm{S}, \mathrm{B}, \mathrm{W}$ & 11. Compaction Layer & & & $\sqrt{ }$ & & \\
\hline \multicolumn{7}{|c|}{ Comments - Interspaces with platy structure at $2-3 \mathrm{~cm}$ depth \& roots tending to grow horizontally at this point; No evidence under shrubs } \\
\hline B & 12. Functional/Structural Groups & $\sqrt{ }$ & & & & \\
\hline \multicolumn{7}{|c|}{ Comments - Tall and short C4 grasses not present; Midgrass C3 grasses restricted to one species; Forb component not present; Shrubs dominate } \\
\hline $\bar{B}$ & 13. Plant Mortality/Decadence & & $\sqrt{ }$ & & & \\
\hline \multicolumn{7}{|c|}{ Comments - Many shrubs have died recently } \\
\hline $\mathrm{B}, \mathrm{W}$ & 14. Litter Amount & & $\sqrt{ }$ & & & \\
\hline \multicolumn{7}{|c|}{ Comments - Only associated with shrubs; no litter around C3 mid-grasses } \\
\hline B & 15. Annual Production & $\sqrt{ }$ & & & & \\
\hline \multicolumn{7}{|c|}{ Comments - Site should support $1800 \mathrm{~kg} / \mathrm{ha}$, but estimate less than $300 \mathrm{~kg} / \mathrm{ha}$} \\
\hline B & 16. Invasive Plants & & & & & $\sqrt{ }$ \\
\hline \multicolumn{7}{|l|}{ Comments } \\
\hline B & 17. Reproductive Capability of Perennial Plants & $\sqrt{1}$ & & & & \\
\hline
\end{tabular}

ecological site description will include a series of accepted narratives for indicators and attributes.

During this step, evaluators may consider adding indicators that they believe should be included in the assessment. Those indicators might include parameters that may not be important nationally, but may have regional importance. An exam- ple of this might be the inclusion of a biological soil crust indicator for specific ecological sites in the Colorado Plateau where these crusts are important for soil stabilization (Belnap and Gardner 1993, Johansen 1993, Warren 2001). Similar to the revised narrative, if an evaluator uses an additional indicator, then they should submit the indicator, the narrative descrip- tions and the attribute(s) to which it relates along with relevant scientific literature that provide evidence of this relationship to the NRCS State Rangeland Management Specialist who will follow the appropriate NRCS protocol for consideration in future ecological site descriptions. These additional indicators must be ecology-based and not value- or use-based indicators. 
Table 6. (a) A hypothetical example of a completed indicator summary, Part 3 of the Rangeland Health Evaluation Summary Worksheet, using the information from Table 5 to show the frequency distribution of indicators for each of the rangeland health attributes and (b) the attribute summary that gives the evaluator's judgment regarding the overall rating for each attribute at the site. Note that italicized text indicates the evaluator's comments regarding the attribute summary.

\begin{tabular}{l|c|c|c|c|c|c} 
a) Indicator Summary & Extreme & $\begin{array}{c}\text { Moderate to } \\
\text { Extreme }\end{array}$ & Moderate & $\begin{array}{c}\text { Slight to } \\
\text { Moderate }\end{array}$ & $\begin{array}{c}\text { None to } \\
\text { Slight }\end{array}$ & $\begin{array}{c}\Sigma \\
\text { Rangeland Health Attributes }\end{array}$ \\
\hline S-Soil/Site Stability (Indicators 1-6, 8,9 \& 11) & & & $\sqrt{ } \sqrt{ }$ & $\sqrt{ } \sqrt{ }$ & $\sqrt{ }$ & 9 \\
\hline W-Hydrologic Function (Indicators 1-5, 7-11 \& 14) & & $\sqrt{ }$ & $\sqrt{ } \sqrt{ } \sqrt{ }$ & $\sqrt{ } \sqrt{ } \sqrt{ }$ & $\sqrt{ }$ & 11 \\
\hline B - Biotic Integrity (Indicators 8-9 \&11-17) & $\sqrt{ } \sqrt{ }$ & $\sqrt{ }$ & $\sqrt{ } \sqrt{ }$ & & $\sqrt{ }$ & 9 \\
\hline
\end{tabular}

b) Attribute Summary- Check the category that best fits the "preponderance of evidence" for each of the 3 attributes relative to the distribution of indicator ratings in the preceding "Indicator Summary" table.

\begin{tabular}{l|c|c|c|c}
\hline \multicolumn{1}{c|}{ Attribute } & Extreme & $\begin{array}{c}\text { Moderate to } \\
\text { Extreme }\end{array}$ & $\begin{array}{c}\text { Moderate } \\
\text { Moderate }\end{array}$ & $\square$ \\
\hline $\begin{array}{l}\text { Soil Site Stability } \\
\text { Rationale: Interspaces all show signs of erosion }\end{array}$ & $\square$ & $\square$ \\
\hline $\begin{array}{l}\text { Hydrologic Function } \\
\text { Rationale: Water appears to be moving on the surface and low } \\
\text { infiltration on the site. }\end{array}$ & $\square$ & $\square$ & $\square$ \\
\hline $\begin{array}{l}\text { Biotic Integrity } \\
\text { Rationale: Only invasive plants indicator was rated higher } \\
\text { than Moderate }\end{array}$ & $\square$ & $\square$ & $\square$ \\
\hline
\end{tabular}

Evaluators must return to the evaluation area to complete the remaining steps. In Step 4, evaluators complete a canopy and ground cover worksheet and a species dominance worksheet similar to those done on the ERA. In addition, evaluators complete the previous structural and functional grouping worksheet by estimating and recording the dominance category of each structural and functional group for the evaluation area. Photographs and quantitative data are again recommended to aid in future interpretations of the site's status.

Step 5 involves rating the 17 indicators using the narrative descriptions for each indicator. These ratings are relative to the ecological site description and the ERA for the specific ecological site. Table 5 includes an example. In Step 6, evaluators summarize the indicator ratings for each attribute and provide a summarized attribute rating for the site (Table 6). Indicator and attribute ratings in these last 2 steps are based on their degree of departure from that expected based on the ecological site description or reference areas. We recognize that the relative importance of different indicators varies among ecological sites, but we do not believe indicators can be properly weighted nor do we believe applicability of indicators for each ecological site can be determined for all ecological sites throughout the nation. In the future, this may be possible and these assessments and comments may be helpful in determining such a weighting or application system.

We recognize that this rating system

appears to lend itself to numerical values or ranks that could be averaged and weighted. Attempts to create numerical

Extreme WIIS Mod. to Ext. MU Moderate Slight to Mod. एس None to Slight

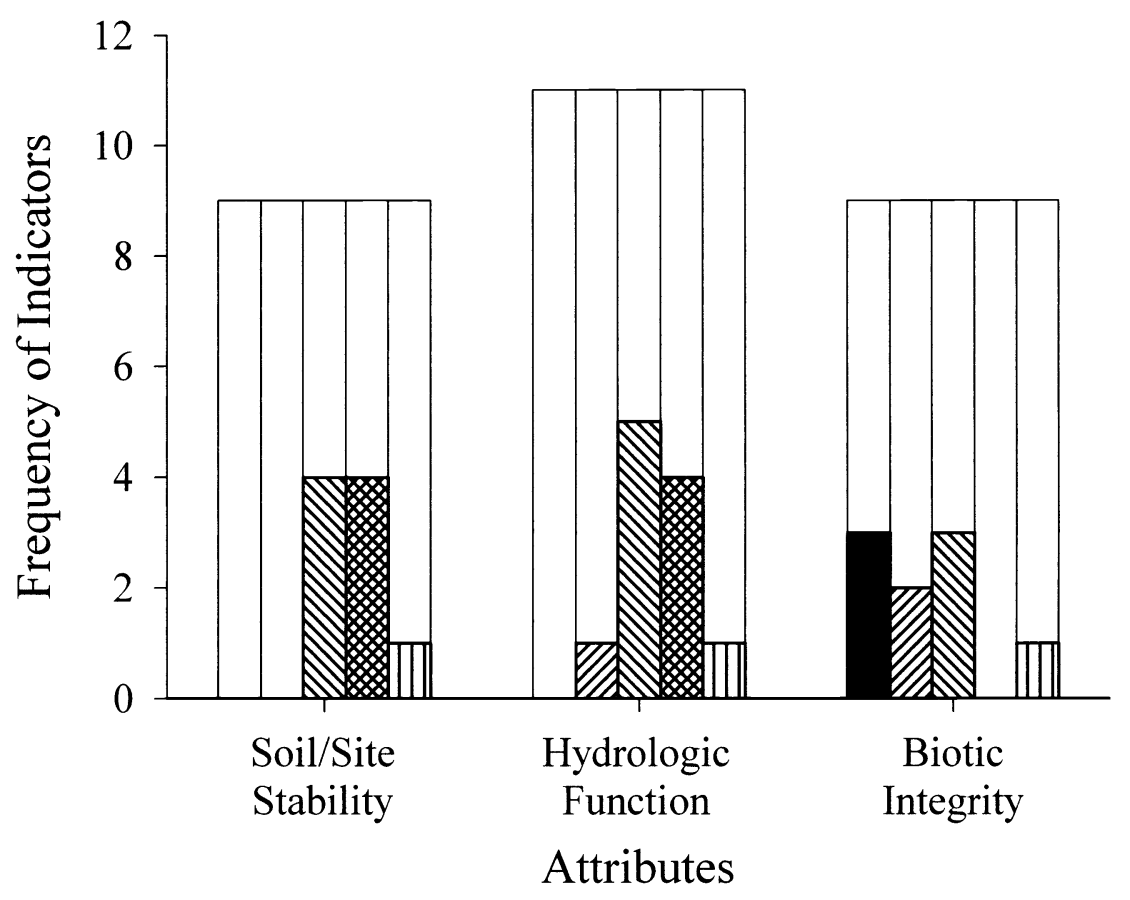

Fig. 1. Example of a histogram used to summarize the indicator categories associated with the 3 rangeland health attributes (adapted from a design by M. Miller, pers. comm.). Open bars indicate the maximum possible frequency for each attribute. 
Table 7. Potential quantitative measurements and indicators that we believe relate to the17 rangeland health qualitative indicators from Pellant et al. (2000) each quantitative indicator, we provide a potential explanation (interpretation) of the relationship between the qualitative and quantitative indicators.

\begin{tabular}{|c|c|c|c|}
\hline Qualitative Indicator & Quantitative Indicator & Measurement & Interpretation \\
\hline 1. Rills & None & & \\
\hline \multirow[t]{2}{*}{ Water flow patterns } & Percent basal cover & Line-point intercept & $\begin{array}{l}\text { Basal cover is negatively correlated with water flow } \\
\text { patterns because plant bases slow water movement. }\end{array}$ \\
\hline & $\begin{array}{l}\text { Proportion of basal gaps }> \\
25,50,100,200 \mathrm{~cm}\end{array}$ & Basal gap intercept & $\begin{array}{l}\text { Basal gaps are positively correlated with water flow } \\
\text { patterns because water gains energy as it moves } \\
\text { unobstructed across larger gaps. }\end{array}$ \\
\hline $\begin{array}{l}\text { 3. Pedestals and/or } \\
\text { terracettes }\end{array}$ & $\begin{array}{l}\text { Standard deviation of pin } \\
\text { heights }\end{array}$ & $\begin{array}{l}\text { Erosion bridge } \\
\text { (microtopography) }\end{array}$ & $\begin{array}{l}\text { Pedestals and terracettes can be positively correlated with } \\
\text { pin height standard deviation because increased } \\
\text { microtopography is sometimes due to pedestals and } \\
\text { terracettes. }\end{array}$ \\
\hline \multirow[t]{2}{*}{ Bare ground } & Percent bare ground & Line-point intercept & $\begin{array}{l}\text { Bare ground is positively correlated with runoff and } \\
\text { erosion. }\end{array}$ \\
\hline & $\begin{array}{l}\text { Proportion of line in canopy } \\
\text { gaps }>25,50,100,200 \mathrm{~cm}\end{array}$ & Canopy gap intercept & $\begin{array}{l}\text { The bare ground qualitative indicator is also positively } \\
\text { correlated with canopy gaps because bare ground in large } \\
\text { gaps usually has a larger effect on many functions than } \\
\text { bare ground in small gaps. }\end{array}$ \\
\hline \multirow[t]{2}{*}{ Gullies } & $\begin{array}{l}\text { Width-to-depth ratio and } \\
\text { side slope angle }\end{array}$ & Channel profiles & $\begin{array}{l}\text { Lower width-to-depth ratios and higher side slope angles } \\
\text { both reflect more severe or active gully erosion. }\end{array}$ \\
\hline & Headcut movement & Headcut location & $\begin{array}{l}\text { Higher rates of headcut movement reflect greater gully } \\
\text { erosion. }\end{array}$ \\
\hline 6. Wind-scoured areas & None & & \\
\hline \multirow[t]{2}{*}{ Litter movement } & $\begin{array}{l}\text { Proportion of litter cover in } \\
\text { interspaces } v s \text {. under } \\
\text { canopies }\end{array}$ & Line-point intercept & $\begin{array}{l}\text { Higher proportions of litter in the interspaces can be } \\
\text { positively related to litter movement. }\end{array}$ \\
\hline & $\begin{array}{l}\text { Proportion of basal gaps }> \\
25,50,100,200 \mathrm{~cm}\end{array}$ & Basal gap intercept & $\begin{array}{l}\text { Basal gaps can be positively related to redistribution or } \\
\text { loss of litter. }\end{array}$ \\
\hline $\begin{array}{l}\text { 8. Soil surface resistance } \\
\text { to erosion }\end{array}$ & $\begin{array}{l}\text { Average soil surface } \\
\text { stability }\end{array}$ & Soil stability kit (surface) & $\begin{array}{l}\text { Surface aggregate stability is positively related to soil's } \\
\text { resistance to wind and water erosion. }\end{array}$ \\
\hline $\begin{array}{l}\text { 9. Soil surface loss or } \\
\text { degradation }\end{array}$ & $\begin{array}{l}\text { Average soil sub-surface } \\
\text { stability }\end{array}$ & Soil stability kit (sub-surface) & $\begin{array}{l}\text { Sub-surface soil structure degrades and organic matter } \\
\text { declines as surface soil is lost, thus sub-surface aggregate } \\
\text { stability is negatively related to soil surface loss or } \\
\text { degradation. }\end{array}$ \\
\hline \multirow{2}{*}{$\begin{array}{l}\text { Plant community } \\
\text { composition and } \\
\text { distribution relative to } \\
\text { infiltration and runoff. }\end{array}$} & Percent composition & $\begin{array}{l}\text { Line-point intercept or } \\
\text { production }\end{array}$ & $\begin{array}{l}\text { Changes in species composition can be related to changes } \\
\text { in infiltration. For example, root and shoot morphology of } \\
\text { tussock vs. stoloniferous plants. }\end{array}$ \\
\hline & $\begin{array}{l}\text { Proportion of basal gaps }> \\
25,50,100,200 \mathrm{~cm}\end{array}$ & Basal gap intercept & $\begin{array}{l}\text { Changes in basal gaps can be related to changes plant } \\
\text { distributions that relate to infiltration and runoff. }\end{array}$ \\
\hline \multirow[t]{2}{*}{ Compaction layer } & $\begin{array}{l}\text { Ratio of penetration } \\
\text { resistance in the upper } 15 \\
\mathrm{~cm} \text { ( } 6 \text { inches) between the } \\
\text { evaluation and reference } \\
\text { area }\end{array}$ & Impact penetrometer & \multirow[t]{2}{*}{$\begin{array}{l}\text { Ratios of penetration resistance or bulk density above } 1 \\
\text { can indicate the presence of a compaction layer. }\end{array}$} \\
\hline & $\begin{array}{l}\text { Ratio of mass-per-volume } \\
\text { of soil in the upper } 15 \mathrm{~cm} \\
\text { between the evaluation and } \\
\text { reference area }\end{array}$ & Bulk density & \\
\hline \multirow{2}{*}{$\begin{array}{l}\text { Plant functional or } \\
\text { structural groups }\end{array}$} & \multirow{2}{*}{$\begin{array}{l}\text { Percent composition by } \\
\text { functional or structural } \\
\text { group and group richness }\end{array}$} & Line-point intercept & \multirow{2}{*}{$\begin{array}{l}\text { Composition and richness of functional or structural } \\
\text { groups are positively related to plant functional or } \\
\text { structural groups qualitative indicator }\end{array}$} \\
\hline & & Production & \\
\hline $\begin{array}{l}\text { 13. Plant mortality or } \\
\text { decadence }\end{array}$ & $\begin{array}{l}\text { Proportion of live-to-dead } \\
\text { canopy }\end{array}$ & Line-point intercept & $\begin{array}{l}\text { The live-to-dead proportion is positively related to the } \\
\text { plant mortality or decadence qualitative indicator }\end{array}$ \\
\hline \multirow[t]{2}{*}{ 14. Litter amount } & Litter mass & Litter mass & \multirow{2}{*}{$\begin{array}{l}\text { The amount of litter mass and cover per unit area is } \\
\text { related to litter amount. }\end{array}$} \\
\hline & Litter cover & Line-point intercept & \\
\hline 15. Annual production & Total annual production & Production & $\begin{array}{l}\text { Productions relates directly with the qualitative indicator } \\
\text { of annual production }\end{array}$ \\
\hline \multirow{2}{*}{$\begin{array}{l}\text { 16. Noxio } \\
\text { plants }\end{array}$} & Density of invasive species & Belt tranect & \multirow{2}{*}{$\begin{array}{l}\text { Number of species and their densities or cover will } \\
\text { directly relate to the qualitative indicator }\end{array}$} \\
\hline & $\begin{array}{l}\text { Percent cover of invasive } \\
\text { species }\end{array}$ & $\begin{array}{l}\text { Modified Whittaker cover } \\
\text { plots }\end{array}$ & \\
\hline $\begin{array}{l}\text { 17. Perennial plant } \\
\text { reproductive capability }\end{array}$ & None & & \\
\hline
\end{tabular}


decision systems and provide weightings for indicators have been proposed (Leininger et al. 1999, Weltz et al. 1999), but since this variation in importance of indicators exists, evaluators should not apply numerical values to indicator categories and determine an average rank for each attribute, nor should they rate the attribute based on the modal category (e.g., the category receiving the greatest number of indicators). Table 6 provides an example of how an evaluator might arrive at a different rating than would be achieved by a rank average. To calculate the average rank, each indicator category is given a whole number-ranked value and the category limits are established as the range of possible ranks divided by the number of categories. In our example, the 5 categories (None-to-Slight to Extreme) are assigned ranks from 1 to 5 , respectively. The category limits among the 5 categories would have a 1.0 unit range (the range of 5 if we use 0.5 and 5.49 as the minimum and maximum, divided by the number of categories, 5). Thus, the average rank for each of the 3 attributes would be 2.3 for Soil and Site Stability, 3.6 for Biotic Integrity, and 2.5 for Hydrologic Function. Using the 1.0 category limits, Soil and Site Stability would be in the Slight-to-Moderate category $(1.5<2.3 \leq$ 2.49), Biotic Integrity in the Moderate-toExtreme $(3.5<3.6 \leq 4.49)$, and Hydrologic Function narrowly falling in the Moderate category $(2.5=2.5 \leq 3.49)$. For Soil and Site Stability, the rank average was one category different than the evaluator's rating. Although this example shows the rank average's summary as being closer to the None-to-Slight category than the evaluator's summary, other examples could illustrate an opposite deviation.

Since indicator weights have not been standardized and since the choice of a weighting system may influence the overall assessment (Weltz et al. 1999), we suggest that evaluators use tick marks or histograms for each category to create a frequency distribution of the indicators within each attribute to assist them in providing their assessment of each attribute (Table 6; Fig. 1). Consequently, the rationale regarding rankings should be recorded on the worksheet (Table $6 \mathrm{~b}$ ) to assist others in interpreting the evaluator's attribute summaries. All worksheets and rating forms should be retained to provide a record of the assessment.

\section{Intended Applications}

This approach was developed as a tool for conducting a moment-in-time qualitative assessment of rangeland status and as a communication and training tool for helping land managers and other interested people to better understand rangeland ecological processes and their relationship to indicators. The qualitative nature of this approach is the major reason why only experienced and knowledgeable people should conduct this technique. We believe an adequate knowledge of the ecological site and soils are necessary to interpret many of the indicators. People with experience in other ecosystems will likely require training and several years of experience to understand the appropriate level of occurrence for indicators in new ecosystems.

Analogous to the way rangeland condition provides a snapshot of vegetation similarity to a potential natural community, this approach provides a snapshot of ecosystem status relative to an expected status for lands within the identified ecological site. Management should not be changed solely on the findings of this approach, but this approach may be used in conjunction with quantitative monitoring data that do provide a temporal assessment of trend, resource use records (livestock, recreation, etc.) and long-term weather information to identify potential causes of current or historic changes in vegetation and soils.

Others have reported on the potential for using earlier versions of this technique to assess trend of ecosystem status over time (Weltz et al. 1999), but at this moment, we are not recommending that people use this or any earlier version of this approach for measuring rangeland trend, the direction of change in rangeland status over time. Our opposition to such a use is based on 2 factors, our lack of repeated attribute ratings at a single location to determine the year-to-year variation in these ratings, and our belief that quantitative techniques are available that would provide better precision in determining rangeland trend.

Although we oppose the use of this technique for determining rangeland trend, we do believe it is an excellent tool for identifying locations where monitoring should be conducted and for narrowing choices of variables to monitor. Potential candidate locations for establishing quantitative monitoring plots are those locations where the qualitative procedure iden- tified several indicators within an attribute with ratings of Moderate or greater deviation from that expected for the ecological site. At those sites, quantitative measurements for each identified indicator should be considered in a monitoring plan (Table 7). Several documents provide suggestions for quantitative monitoring protocols relating to these indicators as well as other more traditional rangeland monitoring procedures (Bonham 1989, Interagency Technical Team 1996, de Soyza et al. 1997, 2000, Herrick et al. 2002).

This qualitative procedure evolved in part from the NRC (1994) approach that advocated a national assessment of rangelands. However, we do not believe that individual site-specific assessments that are used to evaluate rangelands at a local scale should be combined into state or national assessments without at least combining these qualitative attributes with quantitative data, stratifying the landscape into hierarchical strata (e.g., ecological sites and major land resource areas), and applying a statistically valid sampling method. This does not mean that this qualitative procedure cannot be used to provide a preliminary assessment of a management unit such as a pasture or an allotment. When evaluating a management unit, the manager should stratify the unit into ecological sites and topographic positions. Within each stratum, the manager should evaluate a sample of locations with this protocol. Each stratum should be summarized separately. A manager may use the distribution of attribute ratings within a stratum to develop an interpretation of the attribute's status in that stratum and then use the complete set of strata summaries to write an interpretation of the preliminary management unit status.

\section{Modification and Future Development}

We do not believe this technique is final at this stage. The published technical reference indicates that the technique is version 3. The modified ecological reference worksheet presented in this paper documents the next iteration of this technique and we recommend that evaluators who use this modified reference worksheet and cite this paper. Modifications of the technical references will carry later version numbers. This reflects both continuity with earlier versions, and our belief that this technique will be modified in the future as new information is incorporated. 
This is not a fault of the technique, but an acknowledgement of the evolution of scientific understanding about rangeland ecosystems.

The method for modifying narrative descriptions of individual indicators is described under Step 3 above. This method allows individuals to adapt the narrative for local conditions. We are also prepared to modify, increase or reduce the indicators that are currently included. The team that developed this approach will continue to solicit input from individuals at training sessions, from trained individuals who are using this approach or from individuals that are conducting research on the technique or on individual indicators. We will also entertain feedback from groups such as the SRM Rangeland Assessment and Monitoring Committee, the Western Coordinating Committee on Rangeland Research and Assessment, and the interagency MOU group that have offered or been given responsibility for coordinating efforts in this area.

We do believe that consistency among observers is extremely important for any assessment program. Consistency varied among observers and teams using versions 1 and 2 (Rasmussen et al. 1999, Lieninger et al. 1999). We are continuing to evaluate consistency among observers and teams using version 3. First-year results indicate less variation among observers and teams than earlier assessments (D.A. Pyke unpublished data). To our knowledge, temporal consistency of assessments among observers has not been tested. Research on this topic may be warranted.

We will attempt to minimize unnecessary changes, but since we have earlier versions and anticipate later versions, we strongly encourage users to cite the version of the technique they use, and to note any modifications to the indicators or the protocol. Federal agencies will use the version approved by their agency. It is our hope that this procedure will stimulate new research and will create knowledgeable discussions to further our understanding of rangeland assessments leading to new versions of this technique or to better assessment techniques for determining ecosystem status.

\section{Literature Cited}

Anderson, E.W. 1974. Indicators of soil movement on range watersheds. J. Range Manage. 27:244-247.

Bailey, R.G., P.E. Avers, T. King, and W.H. McNab, (eds.), 1994. Ecoregions and subregions of the United States (map 1:7,500,000 scale) with supplementary table of map unit descriptions. USDA, Forest Service, Washington, D.C.

Barnes, K.K., W.M. Carleton, H.M. Taylor, R.I. Throckmorton, and G.E. Vanden Berg (organizers). 1971. Compaction of agricultural soils. Amer. Soc. Agr. Eng., St. Joseph, Mich.

Belnap, J. and J.S. Gardner. 1993. Soil microstructure in soil of the Colorado Plateau: the role of the cyanobacterium Microcoleus vaginatus. Great Basin Natur. 53:40-47.

Belnap, J. and D.A. Gillette. 1998. Vulnerability of desert biological crusts to wind erosion: the influences of crust development, soil texture and disturbance. J. Arid Environ. 39:133-142.

Benkobi, L., M.J. Trlica, and J.L. Smith. 1993. Soil loss as affected by different combinations of surface litter and rock. J. Environ. Quality 22: 657-61.

Blackburn, W.H. 1975. Factors influencing infiltration and sediment production of semiarid rangelands. Nev. Water Resources Res. 11:929-937.

Blackburn, W.H. and F.B. Pierson Jr. 1994. Sources of variation in interrill erosion on rangelands. p. 1-10. In: W.H. Blackburn, F.B. Pierson Jr., G.E. Schuman, and R. Zartman (eds.), Variability in rangeland water erosion processes. Soil Sci. Soc. Amer., Madison, Wis.

Blackburn,W.H. and M.K. Wood. 1990. Influence of soil frost on infiltration of shrub coppice dune and dune interspace soils in southern Nevada. Great Basin Natur. 50:41-46.

Blackburn, W.H., F.B. Pierson, C.L. Hanson, T.L. Thurow, and A.L. Hanson. 1992. The spatial and temporal influences of vegetation on surface soil factors in semiarid rangelands. Trans. Amer. Soc. Agr. Eng. 35:479-486

Blake, G.R. and K.H. Hartge. 1986. Bulk density. p. 363-375. In: A. Klute (ed.), Methods of soil analysis. Part I. Second Ed. Agron. Monogr. 9. Agron. Soc. Amer. and Soil Sci. Soc. Amer., Madison, Wis.

Bond, R.D. and J.R. Harris. 1964. The influence of the mircoflora on the physical properties of soils. I. Effects associated with filamentous algae and fungi. Australian J. Soil Res. 2:111-122.

Bonham, C.D. 1989. Measurements of terrestrial vegetation. Wiley and Sons, New York, N.Y.

Breckenridge, R.P., W.G. Kepner, and D.A. Mouat. 1995. A process for selecting indicators for monitoring conditions of rangeland health. Environ. Monitoring Assess. 36:45-60.

Bryan, R.B. 1987. Processes and significance of rill development. p. 1-16. In: Bryan, R.B. (ed.), Rill erosion: processes and significance. Catena Supplement 8, Catena Verlag, Cremlingen, Germany.

Cerda, A. 1999. Parent material and vegetation affect soil erosion in eastern Spain. Soil Sci. Soc. Amer. J. 63: 362-368.
Chanasyk, D.S. and M.A. Naeth. 1995. Grazing impacts on bulk density and soil strength in the foothills fescue grasslands of Alberta, Canada. Can. J. Soil Sci. 75:551-557.

Chapin, F.S., III. 1993. Functional role of growth forms in ecosystem and global processes. p. 287-312. In: Ehleringer, J.R. and C.B. Field (eds.), Scaling physiological processes: leaf to globe. Academic Press, San Diego, Calif.

Chepil, W.S. 1945. Dynamics of wind erosion IV. The translocating and abrasive action of the wind. Soil Sci. 61:167-171.

Chepil, W.S. and N.P Woodruff. 1963. The physics of wind erosion and its control. Advan. Agron. 15:211-302.

Clements, F.E. 1920. Plant indicators: the relation of plant communities to process and practice. Carnegie Inst. of Washington, Washington, D.C.

Cole, D.N. 1985. Recreational trampling effects on six habitat types in western Montana. Res. Paper INT-350. USDA-USFS Intermountain Res. Station, Ogden, Ut.

Cooper, J.P. (ed.) 1975. Photosynthesis and productivity in different environments. Cambridge Univ. Press, Cambridge, United Kingdom.

Davenport, D.W., D.D. Breshears, B.P. Wilcox, and C.D. Allen. 1998. Viewpoint: sustainability of piñon-juniper ecosystems-a unifying perspective of soil erosion thresholds. J. Range Manage. 51:231-240.

Dawson, T.E. and F.S. Chapin, III. 1993. Grouping plants by their form-function characteristics as an avenue for simplification in scaling between leaves. p. 313-322. In: J.R. Ehleringer, and C.B. Field (eds.), Scaling physiological processes: leaf to globe. Acad. Press, San Diego, Calif.

de Soyza, A.G., W.G. Whitford, and J.E. Herrick. 1997. Sensitivity testing of indicators of ecosystem health. Ecosystem Health 3:44-53.

de Soyza, A.G., J.W. Van Zee, W.G. Whitford, A. Neale, N. Tallent-Hallsel, J.E. Herrick, and K.M. Havstad. 2000. Indicators of Great Basin rangeland health. J. Arid Environ. 45:289-304.

Dormaar, J.F. and W.D. Willms. 1998. Effect of forty-four years of grazing on fescue grassland soils. J. Range Manage. 51:122-126.

Dyksterhuis, E.J. 1949. Condition and management of rangeland based on quantitative ecology. J. Range Manage. 2:104-115.

Friedel, M.H. 1991. Range condition assessment and the concept of thresholds: a viewpoint. J. Range Manage. 5:422-426.

Fryrear, D.W., C.A. Krammes, D.L. Williamson, and T.M. Zobeck. 1994. Computing the wind erodible fraction of soils. J. Soil Water Conserv. 49:183-188.

Gibbens, R.P., J.M. Tromble, J.T. Hennessy, and M. Cardenas. 1983. Soil movement in mesquite duneland and former grasslands of southern New Mexico from 1933 to 1980. J. Range Manage. 36:145-148. 
Gillette, D.A. and T.R. Walker. 1977. Characteristics of airborne particles produced by wind erosion of sandy soil, High Plains of West Texas. Soil Sci. 123:97-110.

Gillette, D.A., I.H. Blifford, and D.W. Fryrear. 1974. The influence of wind velocity on the size distributions of aerosols generated by the wind erosion of soils. J. Geophys. Res. 79:4068-4075.

Goff, B.F., G.C. Bent, and G.E. Hart. 1993. Erosion response of a disturbed sagebrush steppe hillslope. J. Environ. Quality 22:698-709.

Gould, W.L. 1982. Wind erosion curtailed by shrub control. J. Range Manage. 35:563-566.

Gutierrez, J. and I.I. Hernandez. 1996. Runoff and interrill erosion as affected by grass cover in a semi-arid rangeland of northern Mexico. J. Arid Environ. 34:287-295.

Hagen, L.J. 1984. Soil aggregate abrasion by impacting sand and soil particles. Trans. Amer. Soc. Agr. Eng. 27:805-808.

Hanson, W.R. and L.A. Stoddard. 1940. Effects of grazing upon bunch wheatgrass. Amer. Soc. Agron. J. 32:278-289.

Harper, J.L. 1977. Population biology of plants. Academic Press, New York, N.Y.

Hassink, J., L.A. Bouwman, K.B. Zwart, and L. Brussaard. 1993. Relationships between habitable pore space, soil biota, and mineralization rates in grassland soils. Soil Biol. Biochem. 25:47-55.

Hennessy, J.T., R.P. Gibbens, J.M. Tromble, and M. Cardenas. 1983. Vegetation changes from 1935 to 1980 in mesquite dunelands and former grasslands of southern New Mexico. J. Range Manage. 36:370-374.

Hennessy, J.T., B. Kies, R.P. Gibbens, and J.M. Tromble. 1986. Soil sorting by fortyfive years of wind erosion on a southern New Mexico range. Soil Sci. Soc. Amer. J. 50:391-394.

Herrick, J.E., J.R. Brown, A.J. Tugel, P.L. Shaver, and K.M. Havstad. 2002. Application of soil quality to monitoring and management: paradigms from rangeland ecology. Agron. J. 94:3-11.

Herrick, J.E., W.G. Whitford, A.G. de Soyza, J.W. Van Zee, K.M. Havstad, C.A. Seybold, and M. Walton. 2001. Field soil aggregate stability kit for soil quality and rangeland health evaluations. Catena 44:27-35.

Hester, J.W., T.L. Thurow, and C.A. Taylor, Jr. 1997. Hydrologic characteristics of vegetation types as affected by prescribed burning. J. Range Manage. 50:199-204.

Hillel, D. 1998. Environmental Soil Physics. Academic Press, San Diego, Calif.

Hudson, N. 1993. Field measurement of soil erosion and runoff. Food and Agriculture Organization of the United Nations (FAO), Rome, Italy.

Interagency Technical Team. 1996. Sampling Vegetation Attributes. USDI, BLM, National Applied Resource Sciences Center, BLM/RS/ST-96/002+1730, Denver, Colo.

Johansen, J.R. 1993. Cryptogamic crusts of semiarid and arid lands of North America. J. Phycology 29:140-147.
Johnson, C.W. and N.E. Gordon. 1988 Runoff and erosion from rainfall simulator plots on sagebrush rangelands. Trans. Amer. Soc. Agr. Eng. 31:421-427.

Karlen, D.L. and D.E. Stott. 1994. A framework for evaluating physical and chemical indicators of soil quality. p. 53-72. In: J.W Doran, D.C. Coleman, D.F. Bezdicek, and B.A. Stewart (eds.), Defining Soil Quality for a Sustainable Environment, Soil Sci. Soc. Amer. Spec. Pub. Number 35. Soil Sci. Soc. Amer., Madison, Wisc.

Lacey J., P. Husby, and G. Handl. 1990. Observations on spotted and diffuse knapweed invasion into ungrazed bunchgrass communities in western Montana. Rangelands 12:30-32.

Lackey, R.T. 1998. Ecosystem management: paradigms and prattle, people and prizes. Renewable Res. J. 16:8-13.

Larson, W.E. and F.J. Pierce. 1993. The dynamics of soil quality as a measure of sustainable management. p. 27-51. In: J.W Doran, D.C. Coleman, D.F. Bezdicek, and B.A. Stewart (eds.), Defining Soil Quality for a Sustainable Environment, Soil Sci. Soc. Amer. Spec. Pub. Number 35. Soil Sci. Soc. of Amer., Madison, Wisc.

Laycock, W.A. 1991. Stable states and thresholds of range condition on North American rangelands: a viewpoint. J. Range Manage. 44:427-433

Leininger, W.C., G.W. Frasier, M.A. Weltz, and D.S. Yakowitz. 1999. A multi-attribute decision support system for evaluating rangeland health. p. 770-772. In: D. Eldridge, and D. Freudenberger (eds.), People and rangelands, building the future. Proc. VI ${ }^{\text {th }}$ Int Rangeland Congr. VI ${ }^{\text {th }}$ Int. Rangeland Congr., Aitkenvale, Australia.

Martin, S.C. and H.L. Morton. 1993. Mesquite control increases grass density and reduces soil loss in southern Arizona. J. Range Manage. 46:170-175.

Morgan, R.P.C. and D.A. Davidson. 1986. Soil erosion and conservation. Longman Scientific and Technical, Wiley, New York, N.Y.

Morgan, R.P.C., K. McIntyre, A.W. Vickers, J.N. Quinton, and R.J. Rickson. 1997. A rainfall simulation study of soil erosion on rangeland in Swaziland. Soil Technology 11:291-299.

Mueggler, W.F. 1975. Rate and pattern of vigor recovery in Idaho fescue and bluebunch wheatgrass. J. Range Manage. 28:198-204.

NRC (National Research Council). 1994. Rangeland health: new methods to classify, inventory, and monitor rangelands. National Academy Press, Washington, D.C.

O'Hara, S.L., F.A. Street, and T.P. Burt. 1993. Accelerated soil erosion around a Mexican highland lake caused by pre-hispanic agriculture. Nature 362:48-51.

Olson, B.E. 1999. Impacts of noxious weeds on ecological and economic systems. p. 4-18. In: R.L. Sheley and J.K. Petroff (eds.), Biology and management of noxious rangeland weeds. Oregon State Univ. Press, Corvallis, Ore.
Pellant, M. 1996. Use of indicators to qualitatively assess rangeland health. p. 434-435. In: N.E. West (ed.), Rangelands in a sustainable biosphere. Proc. $V^{\text {th }}$ Int. Rangeland Congr. Soc. Range Manage. Denver, Colo.

Pellant, M., P. Shaver, D.A. Pyke, and J.E. Herrick. 2000. Interpreting indicators of rangeland health, version 3 . Technical Reference 1734-6, (ftp://ftp.ftw.nrcs.usda. gov/pub/glti/IntIndRangeHealth.pdf) USDI, BLM, National Sci. and Tech. Center, Denver, Colo. 21-Mar-02.

Pierson, F.B., W.H. Blackburn, S.S. Van Vactor, and J.C. Wood. 1994. Partitioning small scale spatial variability of runoff and erosion on sagebrush rangeland. Water Resources Bull. 30:1081-1089.

Puigdefábregas, J. and G. Sánchez. 1996. Geomorphological implications of vegetation patchiness on semi-arid slopes. p. 1029-1060. In: M.G. Anderson, and S.M. Brooks (eds), Advances in hillslope processes. Vol. 2. Wiley and Sons, London, U.K.

Pye, K. 1987. Aeolian dust and dust deposits. Academic Press. San Diego, Calif.

Pyke, D.A. 1995. Population diversity with special reference to rangeland plants. $p$. 21-32. In: N.E. West (ed.), Biodiversity of rangelands. Natur. Resources Environ. Issues, Vol. IV, College of Natural Resources, Utah State University, Logan, Ut.

Quansah, C. 1985. The effect of soil type, slope, flow rate and their interactions on detachment by overland flow with and without rain. p. 19-28. In: P.D. Jungerius (ed.), Soils and geomorphology. Catena Supplement 6, Catena Verlag, Cremlingen, Germany.

Rapport, D.J., C. Gaudet, J.R. Karr, J.S. Baron, C. Bohlen, W. Jackson, B. Jones, R.J. Naiman, B. Norton, and M.M. Pollock. 1998. Evaluating landscape health: integrating societal goals and biophysical process. J. Environ. Manage. 53:1-15.

Rasmussen, G.A., M. Pellant, and D. Pyke. 1999. Reliability of a qualitative assessment process on rangeland ecosystems. p. 781-782. In: D. Eldridge, and D. Freudenberger (eds.), People and rangelands, building the future. Proc. VI ${ }^{\text {th }}$ Int. Rangeland Congr., VI ${ }^{\mathrm{th}}$ Int. Rangeland Congr., Aitkenvale, Australia.

Rickard, W.H. and L.E. Rogers. 1988. Plant community characteristics and responses. $p$. 109-179. In: W.H. Rickard, L.E. Rogers, B.E. Vaughn, and S.F. Liebetrau (eds.), Shrub-steppe: balance and change in a semiarid terrestrial ecosystems. Developments in agricultural and managed-forest ecology, Elsevier, New York, N.Y.

Satterlund, D.R. and P.W. Adams. 1992. Wildland Watershed Management, $2^{\text {nd }}$ ed. Wiley and Sons, New York, N.Y.

Schlesinger, W.H., J.F. Reynolds, G.L. Cunningham, L.F. Huenneke, W.M. Jarrell, R.A. Virginia, and W.G. Whitford. 1990. Biological feedbacks in global desertification. Sci. 247:1043-1048.

Smith, D.D. and W.H. Wischmeier. 1962. Rainfall erosion. Adv. Agron. 14:109-148. 
Smith, E.L. 1999. The myth of range/watershed health. p. 6-11. In: Tanaka, J.A. (ed.), Riparian and watershed management in the interior northwest: an interdisciplinary perspective. Proc. Symp. Eastern Oregon State Univ., La Grande, Oregon, Sept. 10-12, 1998. Oregon State Univ. Ext. Service Spec. Rep. 1001, Corvallis, Ore.

Soil Science Society of America. 1997. Glossary of soil science terms. Soil Sci. Soc. Am., Madison, Wisc.

Solbrig, O.T., E. Medina, and J.F. Silva. 1996. Biodiversity and savanna ecosystem processes: a global perspective. Springer, New York, N.Y.

Spaeth, K.E., M.A. Weltz, H.D. Fox, and F.B. Pierson. 1994. Spatial pattern analysis of sagebrush vegetation and potential influences on hydrology and erosion. p. 35-50. In: W.H. Blackburn, F.B. Pierson Jr., G.E. Schuman, and R. Zartman (eds.), Variability in rangeland water erosion processes. Soil Sci. Soc. Amer., Madison, Wis.

SRM Glossary Update Task Group. 1998. Glossary of terms used in range management, $4^{\text {th }}$ Ed., Society for Range Management, Denver, Colo.

SRM Task Group (Society for Range Management Task Group on Unity in Concepts and Terminology Committee, Society for Range Management). 1995. New concepts for assessment of rangeland condition. J. Range Manage. 48:271-282.

Stoddard, L.A., A.D. Smith, and T.W. Box. 1975. Range Management. McGraw-Hill, New York, N.Y.

Stohlgren, T.J., D. Binkley, G.W. Chong, M.A. Kalkhan, L.D. Schell, K.A. Bull, Y. Otsuki, G. Newman, M. Bashkin, and Y. Son. 1999. Exotic plant species invade hot spots of native plant diversity. Ecol. Monogr. 69:25-46.

Stringham, T.K., W.C. Krueger, and P.L. Shaver. 2001. States, transitions, and thresholds: further refinement for rangeland applications. Spec. Rep. 1024, Agr. Exp. Sta. Oregon State University, Corvallis, Ore.

Svejcar, T. and J.R. Brown. 1991. Failures in the assumptions of the condition and trend concept for management of natural ecosystems. Rangelands 13:165-167.

Thurow, T.L., W.H. Blackburn, and C.A. Taylor, Jr. 1988. Infiltration and interrill erosion responses to selected livestock grazing strategies, Edwards Plateau, Texas. J. Range Manage. 41:296-302.

Tilman, D. and J.A. Downing. 1994. Biodiversity and stability in grasslands. Nature 367:363-367.

Tilman, D., J. Knops, D. Wedin, P. Reich, M. Ritchie, and E. Siemann 1997. The influence of functional diversity and composition on ecosystem processes. Sci. 277: $1300-1302$.

Tiscareño-Lopez, M., V.L. Lopes, J.J. Stone, and L.J. Lane. 1993. Sensitivity analysis of the WEPP watershed model for rangeland applications. 1. Hillslope processes. Trans. Amer. Soc. Agr. Eng. 36:1659-1672.
USDA, NRCS. 1997. National range and pasture handbook. USDA, NRCS, Grazing Lands Technol. Inst. 190-vi-NRPH, Washington, D.C.

USDA, NRCS. 2001. The PLANTS database, version 3.1 (http://plants.usda.gov). National Plant Data Center, Baton Rouge, La. 18 MAR-02.

USDI, BLM. 1994. Rangeland reform ' 94 final environmental impact statement. USDI, BLM, Washington, D.C.

USDI, BLM. 2001. Instruction Memorandum No. 2001-079, Subject: Transmittal of 4180 Rangeland health standards manual section and handbook and guidance for conducting watershed-based land health assessments. USDI, BLM, Washington, D.C.

Wallace, L.L. 1987. Effects of clipping and soil compaction on growth, morphology and mycorrhizal colonization of Schizachyrium scoparium a $\mathrm{C} 4$ bunchgrass. Oecologia 72:423-428.

Warren, S.D. 2001. Synopsis: influence of biological soil crusts on arid land hydrology and soil stability. p. 349-360. In: J. Belnap, and O.L. Lange (eds.), Biological soil crusts: structure, function and management. Springer-Verlag, Heidelberg, Germany.

Warren, S.D., T.L. Thurow, W.H. Blackburn, and N.E. Garza. 1986. The influence of livestock trampling under intensive rotation grazing on soil hydrologic characteristics. J. Range Manage. 39:491-495.

Watters, S.E., M.A. Weltz, and E.L. Smith. 1996. Evaluation of a site conservation rating system in southeastern Arizona. J. Range Manage. 49:277-284.

Webb, R.H. and H.G. Wilshire. 1983. Environmental effects of off-road vehicles: impacts and management in arid regions. Springer-Verlag, New York, N.Y.

Weltz, L., G. Frasier, and M. Weltz. 2000. Hydrologic responses of shortgrass prairie ecosystems. J. Range Manage. 53:403-409.

Weltz, M.A., M.R. Kidwell, and H.D. Fox. 1998. Influence of abiotic and biotic factors in measuring and modeling soil erosion on rangelands: state of knowledge. J. Range Manage. 51:482-495.

Weltz, M.A., M.R. Kidwell, H.D. Fox, and D. Yakowitz. 1999. Assessing scale issues on semi-arid watersheds with a multi-attribute decision support system. p. 694-695. In: D. Eldridge, and D. Freudenberger (eds.), People and rangelands, building the future. Proc. VI ${ }^{\text {th }}$ Int. Rangeland Congr. VI ${ }^{\text {th }}$ Int. Rangeland Congr., Aitkenvale, Australia.

West, N.E., K. McDaniel, E.L. Smith, P.T. Tueller, and S. Leonard. 1994. Monitoring and interpreting ecological integrity on arid and semi-arid lands of the western United States. Rep. 37. New Mexico State Univ., New Mexico Range Improvement Task Force, Las Cruces, N.M.

Westoby, M., B. Walker, and I. Noy-Meir. 1989a. Opportunistic management for rangelands not at equilibrium. J. Range Manage. $42: 266-274$.
Westoby, M., B. Walker, and I. Noy-Meir. 1989b. Range management on the basis of a model which does not seek to establish equilibrium. J. Arid Environ. 17:235-239.

White, J. 1979. The plant as a metapopulation. Ann. Rev. Ecol. Syst 10:109-145.

Whitford, W.G. 1988. Decomposition and nutrient cycling in disturbed arid ecosystems. p. 136-161. In: E.B. Allen (ed.), The reconstruction of disturbed arid lands. Amer. Assoc. Adv. Sci., Westview Press, Boulder, Colo.

Whitford, W.G. 1996. The importance of the biodiversity of soil biota in arid ecosystems. Biodiver. Conserv. 5:185-195.

Whitford, W.G., A.G. de Soyza, J.W. Van Zee, J.E. Herrick and K.M. Havstad. 1998. Vegetation, soil, and animal indicators of rangeland health. Environ. Monitoring Assess. 51:179-200.

Whittaker, R.H. 1975. Communities and ecosystems, $2^{\text {nd }}$ ed. Macmillan, New York, N.Y.

Willat, S.T. and D.M. Pullar. 1983. Changes in soil physical properties under grazed pastures. Australian J. Soil Res. 22:343-348.

Wicklum, D. and R.W. Davies. 1995. Ecosystem health and integrity. Can. J. Bot. 73:997-1000.

Wood, M.K. and W.H. Blackburn. 1984. Vegetation and soil responses to cattle grazing systems in the Texas Rolling Plains. J. Range Manage. 37:303-308.

Wood, M.K., E. Eckert Jr., W.H. Blackburn, and F.F. Peterson. 1997. Influence of crusting soil surfaces on emergence and establishment of crested wheatgrass, squirreltail, Thurber needlegrass and fourwing saltbush. J. Range Manage. 35:282-87.

Woodley, S., G. Alward, G.L. Iglesias Gutierrez, T. Hoekstra, T.B. Holt, L. Livingston, L.J. Loo, A. Skibicki, A.C. Williams and P. Wirth. 2000. North American test of indicators of sustainable forestry. USFS, Inventory and Monitoring Institute, Rep. No. 3. Fort Collins, Colo. 